\title{
Moral as a form of spiritual culture
}

\author{
Fayziev Turabek Raufovich ${ }^{1}$, Umaralieva Gulchehra Bahodirjonovna ${ }^{2}$ \\ ${ }^{1}$ Associate professor, Director of the networking center for retraining and advanced training of \\ teachers at the State Institute of Arts and Culture of Uzbekistan, Uzbekistan \\ ${ }^{2}$ Senior teacher Senior Lecturer of the Department of Social and Humanities, State Institute of \\ Arts and Culture of Uzbekistan, Uzbekistan
}

Email:fayziev_t@umail.uz

\begin{abstract}
This article discusses Moral as a form of spiritual culture. Morality is a special area of culture and it differs from other forms. Morality is a system of norms of behavior of people accepted in society.
\end{abstract}

Keywords: morality, norm, behavior, society, culture, spirituality.

\section{INTRODUCTION}

Morality is a special area of culture and it differs from other forms. Morality is a system of norms of behavior of people adopted in society. Morality is a special form of public consciousness and a kind of social relations. Morality embraces moral views and feelings, life orientations and principles, the goals and motives of actions and relationships, drawing a line between good and evil, conscience and dishonesty, honor and dishonor, justice and injustice, norm and abnormality, mercy and cruelty, etc.

The concept of «morality» is extremely multivalued. There are several dozens of certain morals. Most often, morality is understood as one of the main ways of normative regulation of human actions in society, as well as a special form of public consciousness and the type of social relations. The roles of morality in the life of society and the individual are numerous. It is difficult to explain why there is morality, but it is clear why it exists. If for other terrestrial creatures the way of life and destiny are prescribed by nature, then man - a historical being - makes up his destiny himself. For him there is no once and for all written law. What is a person can never be decided definitively, for neither history nor our personal destiny is yet complete. Every hour we become different, we are improving according to a program that is not yet available, which we ourselves write ourselves. It's not a question of coming up with a model of the future and deciding how we are going to live. It is much more important to decide what will be ourselves, what will be considered humane and appropriate to man. What will be not only our rights, but also duties? What should we become to be fully called people? Man is always on the path of this search, such a truly human path is morality.

\section{MAIN PART}

The judgment of the wise men that humanity is moving in the direction of good is not an illusion or a good wish, it is the essence of morality. As soon as it is, we are moving along it inevitably. In the field of this aspiration, the functions of morality are realized.

There are different concepts of the origin of morality. The scientific concept asserts that the values and norms of behavior and communication of people gradually evolved in the course of their joint work and everyday life. Already in primitive society, there was a system of taboos in the tribes - the oldest prohibitions on killing relatives, blood ties, etc. With the expansion of ties between genera and tribes, the talion rule (from Latin talio - retribution) - «an eye for an eye, a tooth for a tooth» appears. In agrarian civilizations in the middle of the I millennium BC. to replace talion came the «golden rule of morality» (the simplest universal rule of behavior) - «do unto people as you would have them do unto you.» A big influence on the formation of moral standards is provided by politics and ideology. 
According to the religious concept of the origin of morality, its values and norms are defined by God. In the Christian culture, for example, one of the moral guidelines is the Decalogue - the 10 commandments of the Old Testament: honor the father and mother, do not kill, do not steal, do not commit adultery, do not slander, do not envy, etc. Similar commandments are in the moral codes of other world and national religions.

As moral values, honesty, loyalty, respect for elders, courage, diligence, responsibility, patriotism and other ethical virtues are honored in all peoples. And although in life people do not always show similar qualities, but they are highly valued, and those who possess them are respected. These values act as moral ideals. Moral values and norms are of a concrete historical nature, that is, they have their own specifics in local cultures, change along with changes in the material conditions and spiritual factors of public life. But, since the nature of people is the same, with all the diversity of the known systems of morality, one can still speak of common universal moral values and norms, thanks to which mutual understanding, contact and coexistence of representatives of different cultures is achieved.

\section{DISCUSSIONS}

It guides people to take into account not only their interests, but also the interests of others. Since the nature of people is the same, with all the diversity of known systems of morality, one can speak of common universal moral values and norms, thanks to which mutual understanding and coexistence of representatives of different cultures is achieved. As moral values, honesty, loyalty, respect for elders, courage, diligence, responsibility, patriotism and other ethical virtues are honored in all peoples.

Philosophy is a special form of cognition of the world, a specific form of man's spiritual activity, which develops a system of knowledge about the fundamental principles and foundations of human existence, about the characteristics of the human attitude to nature, society and spiritual life in all its manifestations. In its search, philosophy is based on literature, art, art criticism, political and legal consciousness, ordinary thinking, which is the spiritual part of culture and society.

Being a spiritual expression of human activity, philosophy tries to understand different aspects of the world through the prism of the individuality of the personality of the individual. In philosophy, the main place is given to attempts to rationally explain the world.

Among the diverse functions of philosophy, its prognostic function, its active and active participation in foreseeing and forecasting the ideals of the future, the more perfect arrangement of human life, in search of new ideological orientations, is gaining increasing importance in modern conditions. There is an urgent need to develop such models and scenarios for the development of mankind, when the tendency to increase the unity and integrity of the human community does not contradict the national interests of states, the historically formed spiritual and cultural traditions, the way of life of each people.

\section{CONCLUSION}

The development of universal human values has acquired great urgency. Almost all of the greatest thinkers of our time put this issue on the table anyway. It is possible that in the near future the tendency to gaining a status of philosophy as a kind of vital-practical wisdom will intensify. During its inception, philosophy possessed this status, but then lost it, abstracted from the real needs and requests of a particular living person. Philosophy, apparently, will try to become again - of course, taking into account all the realities of our time - necessary for a person to comprehend and solve problems arising in the course of his daily life.

\section{REFERENCES}

1. Andreev D. Rose of the World. - M., 1992. P. 244.

2. Omar Khayyam. Rubai. - T., 1981. P. 111

3. Farhodzhonova NF The influence of ideological processes on the national idea in the conditions of globalization // The World of Science and Education. - 2016. - No. 2 (6)

4. Mirzakholov Kh. T., Abdurakhmonova BR Self-improvement of personality-the goal of aesthetic education // Young scientist. - 2016. - No. 4. - p. 720-722 